\title{
Diversity and Structure of Miombo Woodlands in Mozambique Using a Range of Sampling Sizes
}

\author{
Noé dos Santos Ananias Hofiço ${ }^{1}$ and Frederico Dimas Fleig ${ }^{2}$ \\ 1. Department of Forest Engineering, Faculty of Agronomic Engineering and Forestry, Zambeze University, P.O. Box 49, Mocuba \\ District, Zambézia Province, Mozambique \\ 2. Department of Forest Sciences, Centre of Rural Sciences, Federal University of Santa Maria, Santa Maria, Rio Grande do Sul, \\ P.O. Box 97105-900, Brazil
}

\begin{abstract}
Forest assessments are essential to understand the tree population structure and diversity status of forests and to provide information for biodiversity recovery planning. Unfortunately, the majority of Miombo woodlands in Mozambique lack of inventory data, and consequently are often insufficient for management. This study aimed to assess the species richness, diversity and structure of Miombo woodlands using a range of sampling sizes in Mocuba district, Mozambique. Plant inventory was carried out in 128 systematically selected sample plots in 71.6 ha, which was divided into eight treatments, i.e., T1: 0.1 ha; T2: 0.25 ha; T3: 0.375 ha; T4: 0.5 ha; T5: 0.625 ha; T6: 0.75 ha; T7: 0.875 ha; T8: 1.0 ha, with 16 repetitions. All stems $\geq 10 \mathrm{~cm}$ diameter at breast height, and species name to evaluate the floristic composition, richness of tree species, diversity and diameter distribution were recorded. A total of 36,535 individuals were recorded, belonging 124 species, 83 genera and representing 31 botanical families. The most important species was the Brachystegia spiciformis Benth. and the richest botanical family was Fabaceae. The forest showed an average of 517 \pm 85 trees/ha, and high species diversity and evenness. Analysis of covariance shows that the intercepts and slope of exponential function for diameter distribution are not significantly different for the eight treatments. Compared with the entire composite forest, inventory means were accurately estimated and size class distributions were well represented for plots $\leq 0.25$ ha, for selecting an efficient sampling design suited to forest characteristics and the inventory's purpose.
\end{abstract}

Key words: Floristic composition, sampling units, species diversity, size class distribution, Miombo woodlands.

\section{Introduction}

The Miombo woodland is the most widespread deciduous woodland formation in Africa, covering an estimated 2.7 million $\mathrm{km}^{2}$ in the Southern and Eastern of the continent receiving greater than $700 \mathrm{~mm}$ mean annual rainfall on nutrient-poor soils [1,2]. Miombo woodland is distinguished from other African savanna. In Miombo woodland, woodland and forest are formed by the dominance of tree species in the family Fabaceae, subfamily Caesalpinioideae, particularly in the genera Brachystegia, Julbernardia and Isoberlinia $[3,4]$, while these genera are seldom found outside Miombo [5, 6]. Miombo is regarded as a vegetation type that has been used by humans since the upper

Corresponding author: Noé dos Santos Ananias Hofiço, M.Sc., research field: forest management.
Pleistocene and maintained by man through a long history of cutting, cultivation and frequent dry season fires over the last 55,000 year [7]. In Mozambique, this woodland covers $70 \%$ of the country $[8,9]$, and traditionally provides a large number of ecosystem goods, hardwood timber, firewood and services [10], particularly in the form of edible species. Thus, it is economically important to livelihood [11, 12].

The composition and structure of Miombo woodland appears superficially to be relatively uniform over large regions, suggesting a broad similarity in key environmental conditions [13, 14]. However, differences in species composition, diversity and structure are more apparent at a local scale [15]. Today, the Miombo woodland is in a state of rapid change and its resources are under increasing pressure as more and more areas are modified or 
transformed [7]. Factors, such as geomorphic evolution of the landscape [16], edaphic factors, principally soil moisture and nutrients [2] and past and present land use, and other anthropogenic disturbances $[6,17]$, have all been implicated. According to Chidumayo [5], anthropogenic activities play a big role in the dynamics of Miombo woodlands. Knowledge of the extent, to which tree and shrub diversity have been shaped, is inadequate. It is believed to be generally driven by a complex interplay of various forces [18]. This woodland have been considered as a disclimax and dependent on fire, however, knowledge about forest successional processes and tree species ecology are poorly understood and are therefore important tasks for researchers of Africa [19, 20].

Accordingly, Kangas and Maltamo [21] and Meilby and Nord-Larsen [22] emphasized the importance of conducting studies of floristic and structural in forests in order to provide the knowledge for maintenance of biodiversity and facilitate the exploration of its products, goods and/or services from a planned and rational way, ensuring the continued flow of these resources. Such biodiversity inventories are best integrated with the timber resource inventories in order that forest management operations can be planned [23]. Unfortunately, Mozambique does not have forest assessment or inventory data for the vast majority of its Miombo woodland, and timber potential is considered to be low. It is essential for inventories to be conducted in all woodland to make available quantitative data on the structure and composition of tree species and the diameter distribution [24]. Therefore, this is one of the tools used for understanding the succession, allowing to prior review of dynamic forest conditions, enabling development of the plant community and for biodiversity recovery planning [22]. This study assessed species richness, diversity and structure of Miombo woodlands using a range of sampling sizes in Mocuba district to predict about the develop forest sampling strategies for biodiversity recovery planning in Mozambican Miombo woodland.

\section{Materials and Methods}

\subsection{The Study Area Description}

The study site was in the Sotomane logging concession, located in Namanjavira administrative post in north part of the Zambézia province, Mozambique (Fig. 1) at latitude 16 $6^{\circ} 33^{\prime} 58^{\prime \prime}$ and $16^{\circ} 49^{\prime} 22^{\prime \prime} \mathrm{S}$, longitude $36^{\circ} 32^{\prime} 57^{\prime \prime}$ and $36^{\circ} 47^{\prime} 39^{\prime \prime} \mathrm{E}$, covering about 40,000 ha.

Mocuba district is located in lower Zambézia and topography is characterized by an almost flat to undulating topography, with low elevation at around 200-400 m altitude above sea level, and by sandy soils with outbreaks of sandstone, calcareous conglomerates and turf soils around the vleis and in the river floodplains. The sands are underlained by sub-littoral sands which accumulate water, enabling them to support very tall trees [25]. The climate of the district is tropical sub-humid and presents two seasons: dry winter from April to October and rainy season from November to March. Total annual precipitation is 1,200 $\mathrm{mm}$ [24]. According to Pereira [24], the mean temperature varies from $22{ }^{\circ} \mathrm{C}$ during dry winter months to $27^{\circ} \mathrm{C}$ for the wet and hot period. October is the hottest month and July is the coldest. Whirlwinds are frequent during the hot dry period.

Vegetation of Sotomane logging concession comprises a mosaic of dry deciduous Miombo woodland and dry lowland forest with a canopy cover of $40 \%-70 \%$, characterized by a variety of species that is dominated by Brachystegia spp., Julbernardia globiflora plant species, three closely related genera from the Fabaceae family, subfamily Caesalpinioideae $[24,26]$. Although the dominance by Caesalpinioideae is characteristic, their contribution to tree numbers and biomass varies extensively within and between communities [9, 10]. The dry Miombo canopy is generally less than $15 \mathrm{~m}$ in height and deciduous for a month or more during the dry season $[3,5]$. 


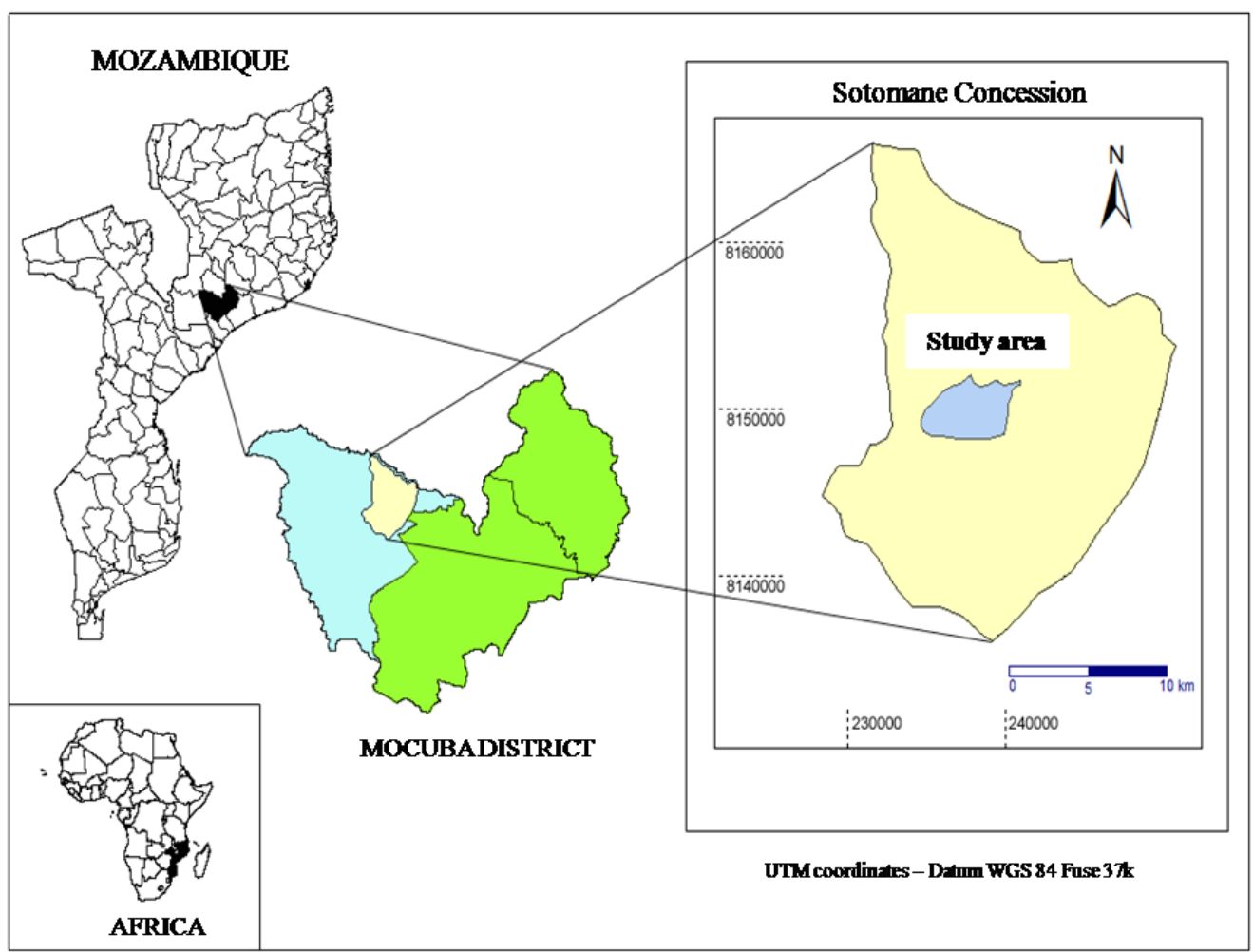

Fig. 1 The geographic location of Sotomane logging concession and the location of the Mocuba district in Mozambique.

\subsection{Sampling Design and Sampling Intensity}

Systematic sampling was adopted (Fig. 2). Under this design, the first sampling unit was randomly selected on the ground, and thereafter, plots were spaced at uniform intervals. The reason for the selection of this design was based on the fact that there was no great variation in the forest vegetation. According to Malimbwi and Mugasha [27], since all parts of the population are represented in the sample, the precision of the parameters estimated is usually high. Field sampling was designed to represent variations over the large spatial extent of the area, and the sampling design resulted in that no plots being placed in forest directly was affected by logging. Areas outside of this core area are intensively managed by concessionaire, and thus are not suitable for determining the natural ecological relationships [28]. The management unit is represented by a systematic sampling grid covering an area, and was preceded by a reconnaissance survey, which involved, as sampling units, 128 fixed-area plots laying-out from the map of the forest concession. The area was gridded into 16 tracks with distant $200 \mathrm{~m}$ from each other, and contained eight randomly allocated units of different sizes and shape rectangular in each lane, kept a minimum distance of $300 \mathrm{~m}$ from each other, to cover the whole woodland area and variation between vegetation. The width of the sampling units was $50 \mathrm{~m}$, which is about the limit that a man can sight into the forest of large individuals [29]. In this study, systematic sampling design ensured an even spread of the samples throughout the woodland area, and thus increase the chances of including all vegetation types. And this design was adopted, because they are easy to use in the woodland [29]. The sample plot was divided into eight treatments (sizes plots): T1: 0.1 ha; T2: 0.25 ha; T3: 0.375 ha; T4: 0.5 ha; T5: 0.625 ha; T6: 0.75 ha; T7: 0.875 ha; T8: 1.0 ha, respectively, a total of 71.6 ha. The length of the tracks followed the north-south direction and width from east to west using a compass [30]. 


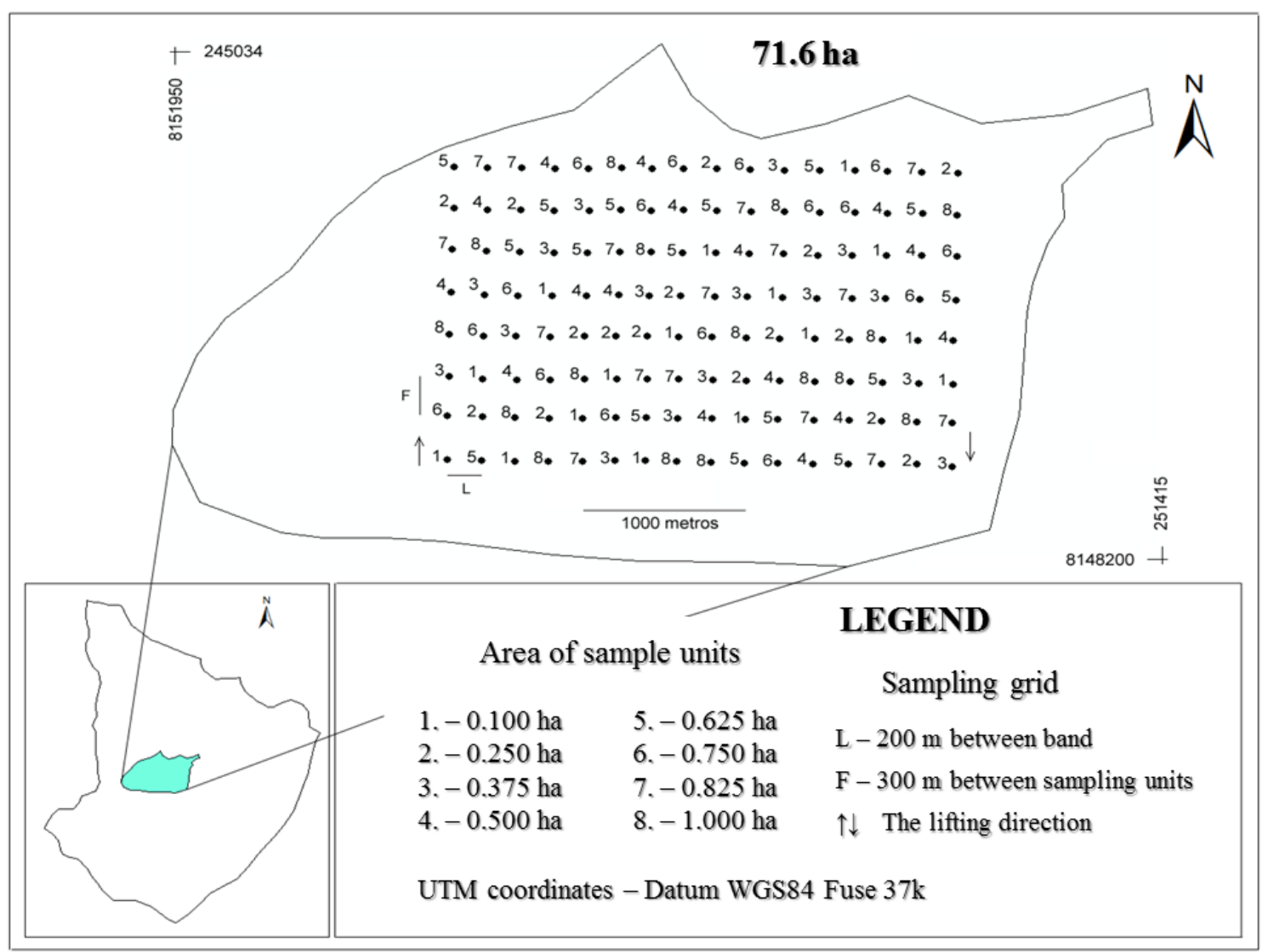

Fig. 2 Structure of the study plots system.

\subsection{Field Measurements}

Traditionally, in Mozambique plot, wise inventory has been used to derive the estimates for forest type level characterization. The plots were established during the dry season from June to October. And at the time of establishment, all trees/stems within the plots with diameter at breast height $(\mathrm{dbh}) \geq 10 \mathrm{~cm}$ were measured, identified to species level, enumerated and numbered using GPS. Trees forking below $1.3 \mathrm{~m}$ were measured and recorded, separately, and at the point, dbh was measured and marked with permanent paint for subsequent re-measurements [31]. Tree species were recorded with the help of traditional botanists and one book guides of "checklist for vernacular plant names in Mozambique" [32]. Any species not identified in the field were taken as voucher specimens for identification at the Eduardo Mondlane University Research Herbarium. The scientific names of the plants are based mainly on the angiosperm philogeneny group III [33, 34].

\subsection{Data Analysis}

\subsubsection{Species Composition and Richness}

The species richness $(S)$ is the number of species recorded in the whole stand. The data were analyzed for species composition, richness, diversity and species importance value index (IVI). To achieve a nearly complete description of species composition and distribution, IVI was used in this study. IVI were computed as the average of the relative basal area, density and frequency. The IVI for a species is a composite of three ecological parameters-relative abundance (density of plants), relative frequency (how often a species occurs in the plots) and relative dominance (density of stock expressed as basal area), which measure different features and characteristics of a species in its habitat [35]. Thus, the IVI provides a 
summary of all three indicators of ecosystem importance and is a frequently used quantifier for vegetation studies. Ecologically, the density and the frequency of a species measure the distribution of a species within the population, while the basal area measures the area occupied by the stems of trees [6].

\subsubsection{Species Diversity and Evenness Index}

Species diversity was computed using Shannon's diversity indexes. The Shannon's diversity index $(H)$ is computed using the following Eq. (1):

$$
H=-\sum_{i=1}^{S}\left(\frac{n_{i}}{n}\right) \times \ln \left(\frac{n_{i}}{n}\right)
$$

where, $n_{i}$ is the number of individuals of species $i$, and $n$ is the overall number of trees inventoried in the plot.

The knowledge of species diversity is useful for establishing the influence of biotic disturbance and the state of succession and stability in the environment $[36,37]$. This species diversity index increases with the number of species in the community $[6,38]$.

The Pielou's evenness $(E q)$ measures the diversity degree of a stand compared with the possible maximum and is computed as Eq. (2):

$$
\begin{gathered}
E q=\frac{H}{H_{\text {max }}} \\
H_{\text {max }}=\ln (S)
\end{gathered}
$$

where, $H_{\max }$ is the maximum value of the Shannon's diversity index of the stand, and $S$ is the number of tree-species recorded in the considered plot $[36,38,39]$.

All diversity and evenness indices were calculated using PC-ORD for Windows version 6.0 [40]. The significance of the influence of the size of the plots on differences of Shannon's diversity index was tested using analysis of variance (ANOVA), and the mean number of individual per species was compared among sample size followed by a post hoc Tukey test.

\subsubsection{Diameter Distribution}

To assess the structure of the forest, the diameter was adjusted according to the Meyer function [20], for a class of individuals dbh for the population and for the eight treatments analyzed separately, using the following Eq. (3):

$$
N_{i}=e^{\left(\beta_{0}+\beta_{1} \cdot c c_{i}\right)}
$$

where, $N_{i}$ and $c c_{i}$ are the number of stems and midpoint of the $i$ th diameter class, respectively, $\beta_{0}$ and $\beta_{1}$ are the parameters of the distribution. The parameter $\beta_{1}$ determines the rate at which trees diminish in successive diameter classes, and $\beta_{0}$ indicates the relative density of the stand [20].

The slopes and elevation were compared between the levels and frequency distributions by class of dbh in the eight treatments assessed by applying ANCOVA [39] to the straight lines obtained by the standard regression method. To determine the differences between treatments and frequency distributions by class of dbh characteristics, data and Meyer function were ln-transformed into a linear model for homogenizing variances with additive error, as Eq. (4):

$$
\ln \left(N_{i}\right)=\beta_{0}+\beta_{1} \cdot c c_{i}
$$

where, $\ln \left(N_{i}\right)$ is the natural logarithm of number of individual by diametric class; $\beta_{0}$ and $\beta_{1}$ are estimated regression coefficient; $c c_{i}$ is class center; $T_{i}$-treatment; $\left(T_{i} \times c c_{i}\right)$-interactions.

The adhesion test Chi-square $\left(\chi^{2}\right)$ was applied to verify the degree of agreement of the frequency distribution of class dbh observed following model proposed by Meyer set [41]. Data analysis was carried out in the Statistical Analysis System 9.2 (SAS Institute Inc., Cary, NC). All the data were considered for each treatment separately as a single entity, or pooled without distinguishing among forest types at significant level $P<0.05$.

\section{Results and Discussion}

\subsection{Species Composition and Richness}

A total of 36,535 stems were identified (Table 1). These represent 31 botanic families and 83 genera. Fabaceae is the largest family with 48 species, followed by Euphorbiaceae with 11 species. None of the other families have more than 10 species. 
Table 1 Tree species composition and richness in the Mocuba district, ranked by IVI.

\begin{tabular}{|c|c|c|c|c|c|c|}
\hline Rank & Tree species & $\begin{array}{l}\text { Number of } \\
\text { individual } \\
\text { specie }\end{array}$ & $\begin{array}{l}\text { Relative } \\
\text { density (\%) }\end{array}$ & $\begin{array}{l}\text { Relative } \\
\text { basal area } \\
(\%)\end{array}$ & $\begin{array}{l}\text { Relative } \\
\text { frequency } \\
(\%)\end{array}$ & IVI $(\%)$ \\
\hline 1 & Brachystegia spiciformis Benth. & 4,020 & 11.0 & 11.1 & 1.9 & 8.0 \\
\hline 2 & Pterocarpus angolensis DC. & 2,381 & 6.5 & 6.3 & 1.9 & 4.9 \\
\hline 3 & Pseudolachnostylis maprouneifolia Pax & 1,791 & 4.9 & 4.9 & 1.9 & 3.9 \\
\hline 4 & Swartzia madagascariensis Desv. & 1,668 & 4.6 & 4.5 & 1.9 & 3.7 \\
\hline 5 & Julbernardia globiflora (Benth.) Troupin & 1,248 & 3.4 & 3.3 & 1.8 & 2.9 \\
\hline 6 & Burkea africana Hook. & 1,132 & 3.1 & 3.1 & 1.7 & 2.6 \\
\hline 7 & Pteleopsis myrtifolia Engl. \& Diels & 1,032 & 2.8 & 2.9 & 1.7 & 2.5 \\
\hline 8 & Brachystegia boehmii Taub. & 873 & 2.4 & 2.4 & 1.8 & 2.2 \\
\hline 9 & Ficus ingens Miq. & 831 & 2.3 & 2.3 & 1.3 & 2.0 \\
\hline 10 & Pericopsis angolensis (Baker) Meeuwen & 743 & 2.0 & 2.0 & 1.8 & 1.9 \\
\hline 11 & Afzelia quanzensis Welw. & 744 & 2.0 & 2.0 & 1.8 & 1.9 \\
\hline 12 & Cordyla africana Lour. & 798 & 2.2 & 2.3 & 1.2 & 1.9 \\
\hline 13 & Erythrophleum suaveolens (Guill. \& Perr.) Brenan & 734 & 2.0 & 2.0 & 1.6 & 1.9 \\
\hline 14 & Dalbergia melanoxylon Guill. \& Perr. & 677 & 1.9 & 1.7 & 1.8 & 1.8 \\
\hline 15 & Combretum imberbe Wawra & 624 & 1.7 & 1.8 & 1.6 & 1.7 \\
\hline 16 & Millettia stuhlmannii Taub. & 558 & 1.5 & 1.6 & 1.7 & 1.6 \\
\hline 17 & Brachystegia bussei Harms & 610 & 1.7 & 1.7 & 1.1 & 1.5 \\
\hline 18 & Parinari curatellifolia Planch. ex Benth. & 539 & 1.5 & 1.4 & 1.5 & 1.5 \\
\hline 19 & Kirkia acuminata Oliv. & 509 & 1.4 & 1.4 & 1.5 & 1.5 \\
\hline 20 & Pseudobersama mossambicensis (Sim) Verdc. & 422 & 1.2 & 1.3 & 1.6 & 1.4 \\
\hline Others & & 14,601 & 38.9 & 40.0 & - & 36.9 \\
\hline Total & & 36,535 & 100 & 100 & 100 & 100 \\
\hline
\end{tabular}

The species richness (124 species) of trees and the densities of species from the Fabaceae family observed in this study compare well with the Miombo woodland occurring in other areas. In Mozambique, Ribeiro et al. [10] enumerated 79 species in Niassa Forest Reserve, while Williams et al. [9] found 69 species around Gorongosa National Park. In Kitulanghalo Forest Reserve and Ihombwa village, Backéus et al. [1] and Mbwambo et al. [42] found 79 and 86 species, respectively, from Tanzania's Miombo woodland. The average tree density of $517 \pm 85$ trees/ha in Miombo woodland is comparable with those reported by Backéus et al. [1], Campbell et al. [2], Kalaba et al. [4] and Chidumayo [5].

The 20 most IVI of occurring tree species are summarized as descending order in Table 1. In terms of IVI, the most important species in mature woodland in this area are Brachystegia spiciformis Benth., Pterocarpus angolensis DC., Pseudolachnostylis maprouneifolia Pax var. Maprouneifolia, Swartzia madagascariensis Desv., Julbernadia globiflora (Benth.) Troupin, Burkea africana Hook., Pteleopsis myrtifolia Engl. \& Diels., Brachystegia boehmii Taub., Ficus ingens Miq. and Pericopsis angolensis (Baker) Meeuwen. They together compose $34 \%$ of the total IVI. These species are typical of the dry Miombo systems of this eco-region $[6,43,44]$. The results also show that the study site is dominated by 20 species and they represent $53 \%$ of all the trees. The dominance by a several species is an indication of a high diverse forest site in terms of tree species.

It was also found that adult population of Dalbergia melanoxylon Guill. \& Perr., Millettia stuhlmannii Taub. and other economic tree species were in low densities (average of 1 tree/ha), and that lack of sapling recruitment to adult population was an increasing problem. Palgrave et al. [26] found that $D$. melanoxylon, like many other timber species, is in 
only a few locations in Mozambique in very small numbers per ha. In fact, throughout Africa, the densities of these economically important tree species, such as D. melanoxylon, are low occurring in isolated forest plots, and their existence is owing to traditional conservation practices $[18,29]$. Worthwhile to mention is the presence of Combretum species, which are not so typical of undisturbed Miombo but tend to occupy more perturbed areas [10, 28, 35, 45].

\subsection{Species Diversity and Evenness Index}

The study revealed that the species richness ranged from 93 to 124 trees, and Shannon-Wiener index of diversity $(H)$ and the Pielou index $(E q)$ ranged from 3.03 to 3.64 and 0.81 to 0.88 , respectively, among treatments over a total survey area of 71.6 ha (Table 2). An ecosystem with $H$ value greater than 2.0 has been regarded as medium to high diverse in terms of species [6].

Thus, study results further showed a higher diversity than other studies in the Miombo region, such as in Mozambique where Shannon indexes of 1.25 were obtained [9], and 1.05 from Tanzania's Miombo by Shirima et al. [46], but similar to diversity (3.40, 2.90 and 3.10, respectively) in the landscapes of the Handeni Hill Forest Reserve, in Tanzania [47]. The $H$ value (3.03-3.64) from the present study is probably due to previous disturbances, which opened the canopy and enabled regeneration of light tolerant genus, like Combretum [10]. Likewise, the existing management practiced has probably made regenerating species to come up vigorously.

The results also showed that there were significant differences by the $F$ test for the diversity of Shannon index between the treatment, and by the Tukey test, it was observed that $\mathrm{T}_{1}(0.1$ ha) was significantly differed from the others $(F=9.89 ; P<0.01)$. This suggests that although the high floristic diversity of the study area was observed, but sampling unit size of $\mathrm{T}_{1} \quad(0.1$ ha) did not capture the floristic representativeness. It should be noted that the size of sample unit of $\mathrm{T}_{6}(0.75 \mathrm{ha})$ showed no statistically significant differences for the diversity compared to other sizes of sampling units (treatments). This fact is explained by the presence of rocky outcrop in some sample units of such treatments. And the fact confirmed within the study area limited the occurrence of some species, like Khaya anthotheca, Pseudobersama mossambicensis and Entandrophragma caudatum. On the other hand, Pereira [24] observed that the history of human disturbance in the past caused the change in floristic composition and diversity in different parts of the forests in Mocuba district. Previous disturbances from bush fire, over harvesting and grazing opened the woodland canopy and gave the way for more regeneration in the woodland $[6,21]$. These results would help to understand more about the impact of human disturbance on biodiversity [7].

\subsection{Diameter Distributions}

The observed distribution of tree species follows an inverse $J$-shaped trend for the eight treatments (Fig. 3). Tree frequency decreases with the increasing diameter, which is common for natural forests with active regeneration and recruitment for the eight treatments analyzed [46, 48].

Table 2 The general characteristics of tree and resources in the Mocuba district.

\begin{tabular}{lllllllll}
\hline Parameter & \multicolumn{7}{c}{ Size of sampling unit (ha) } \\
\cline { 2 - 9 } & 0.1 & 0.25 & 0.375 & 0.5 & 0.625 & 0.75 & 0.875 & 1.0 \\
\hline Richness (total number of species) & 103 & 118 & 119 & 93 & 96 & 108 & 103 & 124 \\
Shannon index $(H)$ & $3.03^{\mathrm{a}}$ & $3.50^{\mathrm{b}}$ & $3.41^{\mathrm{b}}$ & $3.55^{\mathrm{b}}$ & $3.64^{\mathrm{b}}$ & $3.43^{\mathrm{b}}$ & $3.57^{\mathrm{b}}$ & $3.59^{\mathrm{b}}$ \\
Pielou index $(E q)$ & 0.86 & 0.85 & 0.82 & 0.88 & 0.87 & 0.83 & 0.86 & 0.81 \\
Density (stems/ha) & 525 & 519 & 542 & 518 & 583 & 432 & 512 & 517 \\
Stems sampled & 840 & 2,075 & 3,252 & 4,140 & 5,826 & 5,178 & 6,958 & 8,266 \\
\hline
\end{tabular}

\footnotetext{
${ }^{\mathrm{a}, \mathrm{b}}$ Same letters do not differ statistically among themselves at the significance level of $5 \%$ according to the Tukey's test.
} 

Using a Range of Sampling Sizes

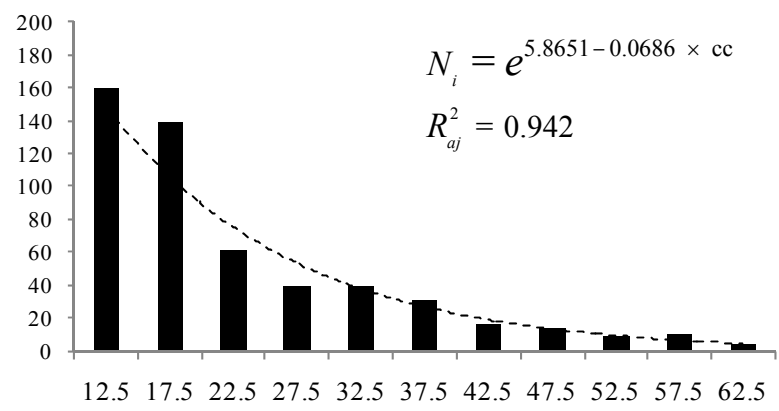

(a) 0.1 ha

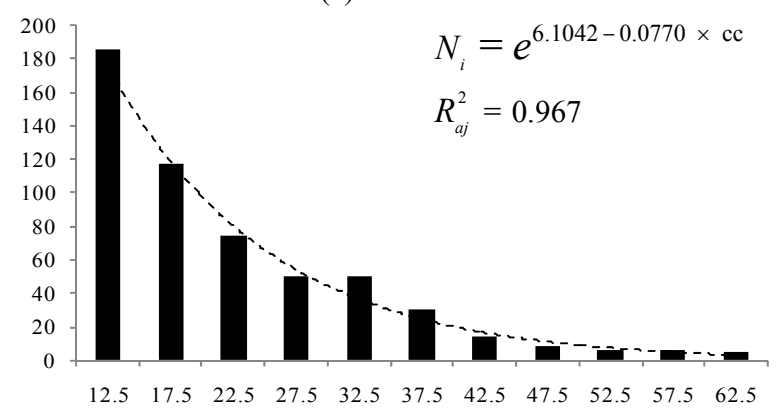

(c) 0.375 ha

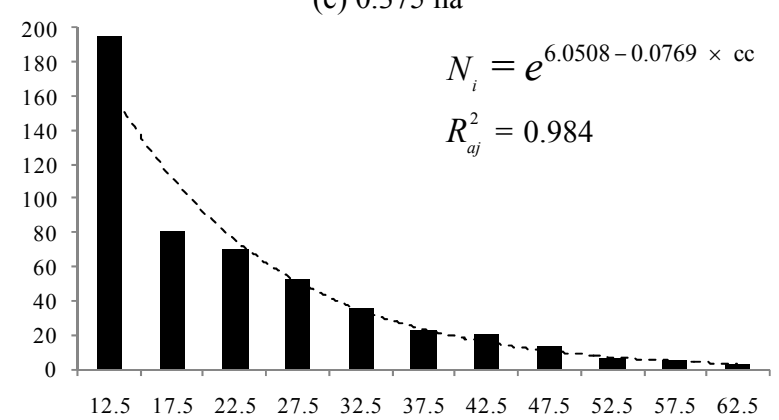

(e) 0.625 ha

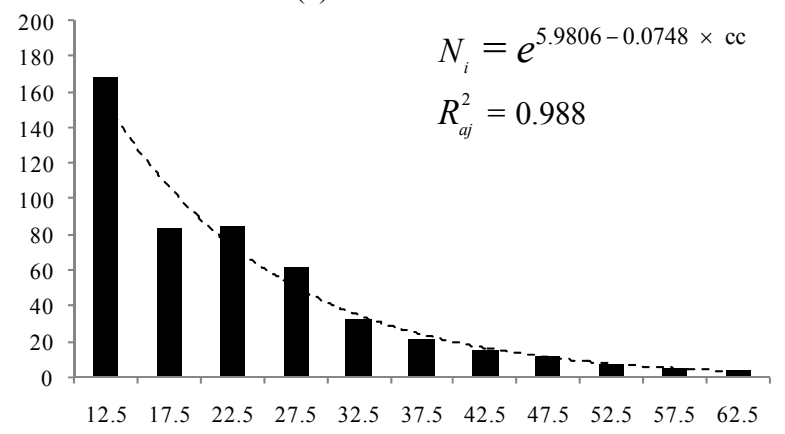

(g) 0.875 ha

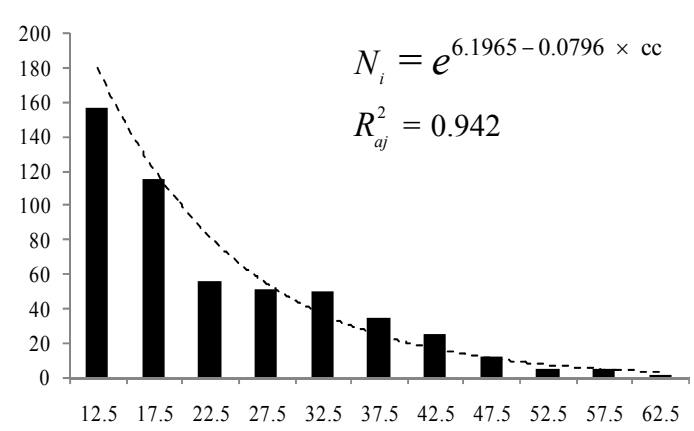

(b) $0.25 \mathrm{ha}$

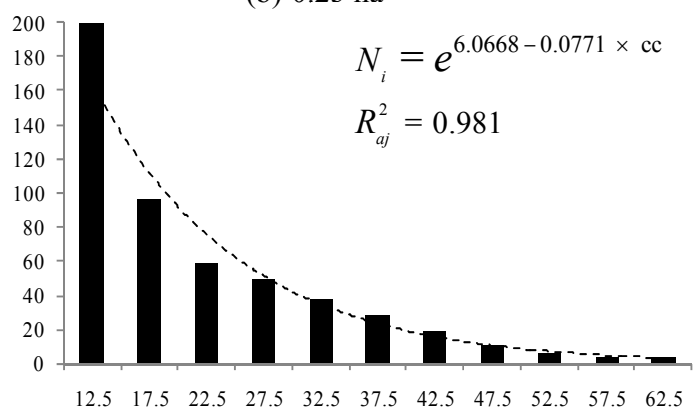

(d) 0.5 ha

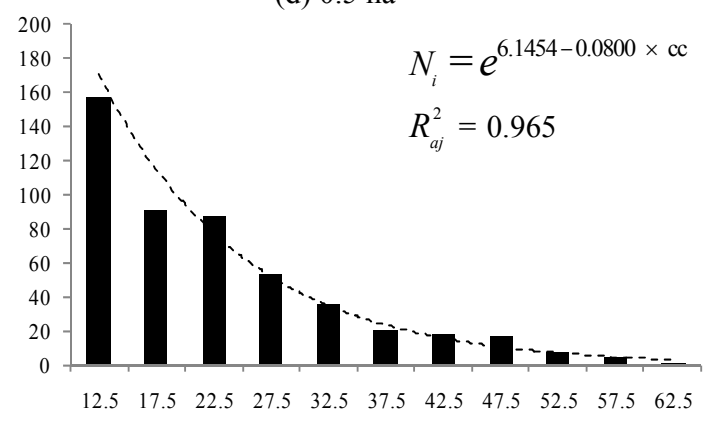

(f) $0.75 \mathrm{ha}$

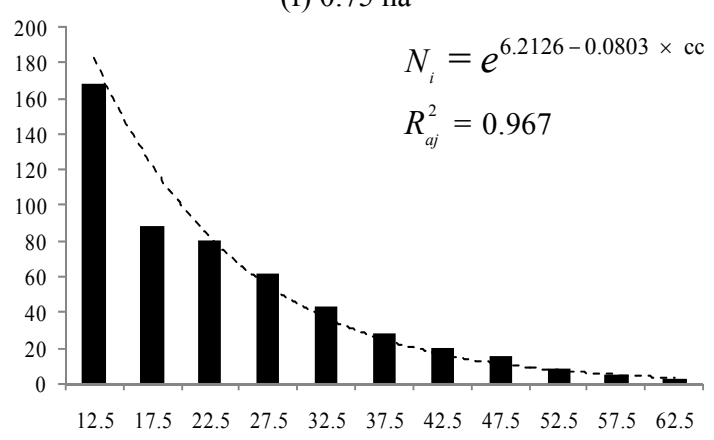

(h) $1.0 \mathrm{ha}$

Fig. 3 Observed and predicted relative diameter distributions of the eight treatments.

cc: class center.

The histograms represent the observed distributions by diameter class (sample plots $=128$ ). The short dashes show the distribution predicted by the negative exponential Meyer function.

In study area, there are different diameter distributions in different treatments, and human disturbances were found in all treatments, which were probably linked with illegal activities and bush fire.
All activities carried out in the woodland were under the supervision of village natural resource committees. However, absolute protection from illegal activities seems to be difficult, because of big demand of the 
wood land products for their livelihoods. According to Norfolk et al. [25], few illegal activities still exist and usually are caused by people coming from non-participating villages known to have problem of firewood and charcoal. Disturbances in Miombo woodlands, such as harvesting of trees by humans for fuel and building materials are likely to greatly change the size class distribution of the harvested, may manipulate the composition and structure of tree species diversity species and also result in increased mortality [18]. Active regeneration and recruitment in Mocuba area as portrayed in this study is a good sign of sustainability of the woodland stock, which has chances of insuring sustainable supply of products and services and hence sustaining livelihoods of the woodland dependents [19]. However, Miombo woodland trees colonize faster and densely after disturbances. This happens due to the exposure of forest floor to sunlight and reduced competition among woody plants [5, 49].

On the other hand, the adhesion test $\chi^{2}$ average of diametric distribution was below the critical value at the critical level of $\alpha=5 \%$, except $\mathrm{T}_{1}\left(\chi^{2}=19.95 ; d f=\right.$ 10) and $\mathrm{T}_{2}\left(\chi^{2}=27.90 ; d f=10\right)$, which showed the value of $\chi^{2}$ tabulated. This indicates non-rejection of the null hypothesis for the treatments that the average value of $\chi^{2}$ is below the critical value. It is concluded that the observed and expected frequencies are similar in a statistical point of view and were adherent to $\alpha=$ $5 \%$. In this area, trees of larger diameter class $(d>20$ $\mathrm{cm})$ were observed to be less dominant in the woodland, and this diameter class most probably suffered from the past degradation and disturbances from anthropogenic activities [9]. Trees of larger diameter classes are more suitable for commercial timber extractions, charcoal marking and firewood or construction materials [6]. This diameter class seems to be over exploited in the past with few remaining trees or limited recruitment from lower diameter classes.

From the results in Table 3, it is observed that all treatments presented for the ANCOVA showed no significant probability for interaction of $T_{\mathrm{i}} \times c c_{i}(P=$ 0.6137), indicating that there are no differences between slopes in the frequency distribution by diameter class for the eight treatments. No significance was also observed in $T_{i}(P=0.8741)$, showing that there are no differences between levels in the frequency distribution by class of dhb in the eight treatments. There were not any pairs of treatment to be found significant differences in slopes and elevations.

Results show that the eight treatments assessed not different regressions based on levels and slopes of the curves of frequency distribution by class of dbh. This allows the use of the same function to describe the frequency distribution by class of dbh to eight treatments [50]. In Tanzania, Mwakalukwa et al. [51] achieved similar results by adjusting Meyer function using 46 sample units of different sizes, which had no statistical difference in level and inclination regardless of size variation.

Table 3 Effects of size plot (treatments) and diametric distribution on number of individual by diametric class in Miombo woodland at the study sites assessed by analysis of covariance.

\begin{tabular}{llllll}
\hline Source of variation & Degrees of freedom & Sum of squares & Mean squares & $F$ value & Probability \\
\hline Model & 15 & 130.1472 & 8.6764 & 167.37 & $<0.0001$ \\
$c c_{i}$ & 1 & 129.7082 & 129.7082 & 2502.09 & $<0.0001$ \\
$T_{i} \times c c_{i}$ & 7 & 0.2796 & 0.0399 & 0.77 & 0.6137 \\
$T_{i}$ & 7 & 0.1595 & 0.0228 & 0.44 & 0.8741 \\
Error & 72 & 3.7325 & 0.0518 & & \\
Total & 87 & 133.8797 & & & \\
\hline
\end{tabular}

$c c_{i}$ : class center; $T_{i}$ : treatment; $T_{i} \times c c_{i}$ : interactions. 


\section{Conclusions}

The study area revealed that there is a reasonably good tree species composition and richness. Species noted to be both dominant and with high species diversity indices include B. spiciformis (8.0), $P$. angolensis (4.9), $P$. maprouneifolia (3.9), $S$. madagascariensis (3.7) and J. globiflora (2.9). These dominant as well as highly diverse tree species fit quite well within the general definition of Miombo woodland. However, it was observed that the stand is characterized by the concentration of a lot of individuals in a few species and plant families, as well as a large number of locally rare species, such as $D$. melanoxylon, M. stuhlmanni and $K$. anthotheca. This may be related to activity logging, being linked to management practices adopted. Generally, the number of individuals in the first diametric classes was higher in eight treatments. It indicates a good sign of sustainability of the woodland stock, which has chances of ensuring sustainable supply of products and services and hence sustains livelihoods of the surrounding communities. For selecting an efficient sampling design, suited to forest characteristics and the inventory's purpose were well represented for plots $\leq 0.25$ ha.

The structural variations between plots samples showed significant differences in the diversity of species. Additionally, there was significant variability in the structural patterns in terms of diametric distribution by diameter class between treatments analyzed. The diameter structure of the forest management unit analyzed showed no differences using regression and slope-fitting techniques. This suggests sustainability of the production volume in the area, which is characterized by a low density of exploration. The results of this study apply to various spatial inventory levels and represent the most important woodland types in Mozambique. Further research is required with respect to different woodland types in other parts of the country.

\section{Acknowledgments}

The authors are grateful to the National Council for Scientific and Technological Development (CNPq, Brazil) and Ministry of Science and Technology, Higher and Technical Vocational Education of Mozambique (MCTESTP) for providing financial support for this study. The authors are also thankful to all people who assisted in the data collection in the study area, as well as village leaders for providing the required information for this study. A special thanks to Deonaldo Lopes and Alexandre Pita for revising the English version and Thomas Schroder for very thoughtful comments on the manuscript.

\section{References}

[1] Backéus, I., Pettersson, B., Strömquist, L., and Ruffo, C. 2007. "Tree Communities and Structural Dynamics in Miombo (Brachystegia-Julbernardia) Woodland, Tanzania." Forest Ecol. Manage. 230: 171-8.

[2] Campbell, B. M., Angelsen, A., Cunningham, A., Katerere, Y., Sitoe, A., and Wunder, S. 2008. "Miombo Woodlands-Opportunities and Barriers to Sustainable Forest Management." CIFOR, Bangor. Accessed July 25, $2014 . \quad$ https://energypedia.info/images/6/6d/ Miombo2007.pdf.

[3] Frost, P. G. H. 1996. "The Ecology of Miombo Woodlands." In The Miombo in Transition: Woodlands and Welfare in Africa, edited by Campbell, B. Bogor, Indonesia: Center for International Forestry Research (CIFOR), 11-57.

[4] Kalaba, F. K., Quinn, C. H., Dougill, A. J., and Vinya, R. 2013. "Floristic Composition, Species Diversity and Carbon Storage in Charcoal and Agriculture Fallows and Management Implications in Miombo Woodlands of Zambia." Forest Ecol. Manage. 304: 99-109.

[5] Chidumayo, E. N. 1997. Miombo Ecology and Management: An Introduction. London: Stockholm Environment Institute and Intermediate Technology.

[6] Giliba, R. A., Boon, E. K., Kayombo, C. J., Musamba, E. B., Kashindye, A. M., and Shayo, P. F. 2011. "Species Composition, Richness and Diversity in Miombo Woodland of Bereku Forest Reserve, Tanzania." $J$. Biodiver. 2: 1-7.

[7] Chidumayo, E. N. 2013. "Forest Degradation and Recovery in a Miombo Woodland Landscape in Zambia: 22 Years of Observations on Permanent Sample Plots." Forest Ecol. Manage. 291: 154-61. 
[8] Nhantumbo, I., Dent, J. B., and Kowero, G. "Goal Programming: Application in the Management of the Miombo Woodland in Mozambique." Euro. J. Oper. Res. 133 (2): 310-22.

[9] Williams, M., Ryan, C. M., Rees, R. M., Sambane, E., Fernando, J., and Grace, J. 2008. "Carbon Sequestration and Biodiversity of Re-growing Miombo Woodlands in Mozambique." Forest Ecol. Manage. 254 (2): 145-55.

[10] Ribeiro, N. S., Shugart, H. H., and Washington-Allen, R. 2008. "The Effects of Fire and Elephants on Species Composition and Structure of the Niassa Reserve, Northern Mozambique." Forest Ecol. Manage. 255 (5-6): 1626-36.

[11] Brouwer, R., and Falcão, M. P. 2014. "Wood Fuel Consumption in Maputo, Mozambique." Biomass Bioenergy 27 (3): 233-45.

[12] Falcão, M. P., Sumaila, R., Grundy, I., and Geldenhuys, C. 2007. "The Impact of Policy on Resource Use in Mozambique: A Case Study of Savane." Silva Lusitana 15 (1): 89-102.

[13] Campbell, B. M., Frost, P., and Bryon, N. 1996. "Miombo Woodlands and Their Use: Overview and Key Issues." In The Miombo in Transition: Woodlands and Welfare in Africa, edited by Campbell, B. Bogor, Indonesia: Center for International Forestry Research (CIFOR), 1-10.

[14] Chirwa, P. W., Syampungani, S., and Geldenhuys, C. J. 2008. "The Ecology and Management of the Miombo Woodlands for Sustainable Livelihoods in Southern Africa: The Case for Non-timber Forest Products." Southern Forests 70 (3): 237-45.

[15] Mapaure, I. N., and Campbell, B. M. 2002. "Changes in Miombo Woodland Cover in and around Sengwa Wildlife Research Area, Zimbabwe, in Relation to Elephants and Fire." Afric. J. Ecol. 40: 212-9.

[16] Schwartz, M. W., and Caro, T. M. 2003. "Effect of Selective Logging on Tree and Understory Regeneration in Miombo Woodland in Western Tanzania." Afric. $J$. Ecol. 41 (1): 75-82.

[17] Chidumayo, E. N. 2004. "Development of Brachystegia-Julbernardia Woodland after Clear-Felling in Central Zambia: Evidence for High Resilience." Applied Veget. Sci. 7 (2): 237-42.

[18] Luoga, E. J., Witkowski, E. T. F., and Balkwill, K. 2004. "Regeneration by Coppicing (Resprouting) of Miombo (African Savanna) Trees in Relation to Land Use." Forest Ecol. Manage. 189: 23-35.

[19] Lupala, Z. J. 2009. "The Impact of Participatory Forest Management on Miombo Woodland Tree Species Diversity and Local Livelihoods: Case Study of Bereku Miombo Woodland, Babati District, Tanzania.” M.Sc. thesis, University of Agricultural Sciences, Uppsala,
Swedish.

[20] Meyer, H. A. 1952. "Structure, Growth and Drain in Balanced Unevenaged Forests." J. Fores. 50: 85-92.

[21] Kangas, A., and Maltamo, M. 2006. Forest Inventory: Methodology and Applications. Dordrecht: Springer.

[22] Meilby, H., and Nord-Larsen, T. 2012. "Spatially Explicit Determination of Individual Tree Target Diameters in Beech.” Forest Ecol. Manage. 270: 291-301.

[23] Sterba, H. 2004. "Equilibrium Curves and Growth Models to Deal with Forests in Transition to Unevenaged Structure: Application in Two Sample Stands." Silva Fennica 38 (4): 413-23.

[24] Pereira, C. R. 2006. "Estimating and Mapping Forest Inventory Variables Using the K-NN Method: Mocuba District Case Study, Mozambique.” Ph.D. thesis, Tuscia University, Italy.

[25] Norfolk, S., Nhantumbo, I., and Pereira, J. 2003. "The New Communities: Land Tenure Reform and the Advent of New Institutions in Zambezia Province, Mozambique." Sustainable Livelihoods in Southern Africa, Institute of Development Studies, Brighton, Research Paper 12. Accessed March 2003. https://www.ids.ac.uk/files/wRP12.pdf.

[26] Palgrave, M. C., Van Wyk, A. E., Jordaan, M., White, J. A., and Sweet, P. 2007. "A Reconnaissance Survey of the Woody Flora and Vegetation of the Catapú Logging Concession, Cheringoma District, Mozambique." Bothalia 37: 57-73.

[27] Malimbwi, R. E., and Mugasha A. G. 2001. Inventory Report of Kitulangalo Forest Reserve, Morogoro, Tanzania. Forest and Beekeeping Division, Dar es Salaam.

[28] Hofiço, N. D. S. A. 2014. "Sampling Sufficiency in a Miombo Woodlands in Mocuba District, Zambézia Province, Mozambique." M.Sc. thesis, Universidade Federal de Santa Maria, Santa Maria, Rio Grande do Sul, Brazil. (in Portuguese)

[29] Opulukwa, M. J., Hamza, K. F. S., and Malende, Y. H. M. B. 2002. "Inventory of Dalbergia melanoxylon (Mpingo) in the Southern Part of Tanzania: The Case of Nachingwea." African Study Monographs 23: 1-10.

[30] Osman, E. M. H., and Idris, E. L. Z. A. 2012. "Comparative Study on the Efficiency of Some Selected Sampling Designs in Assessing Miombo Woodland." J. Fores. Prod. Indus. 1: 4-10.

[31] Munishi, P. K. T., Mringi, S., Shirima, D. D., and Linda, S. K. 2010. "The Role of the Miombo Woodlands of the Southern Highlands of Tanzania as Carbon Sinks." $J$. Ecol. Nat. Enviro. 2 (12): 261-9.

[32] De Koning, J. 1993. Checklist of Vernacular Plant Names in Mozambique. Wageningen: Wageningen Agricultural University. 
[33] The Angiosperm Phylogeny Group. 2009. "An Update of the Angiosperm Phylogeny Group Classification for the Orders and Families of Higher Plants: APG III." Bot. J. Linn. Soci. 161: 105-21.

[34] Brummitt, R. K., and Powell, C. E. 1992. Authors of Plant Names: A List of Authors of Scientific Names of Plants, with Recommended Standard Forms of Their Names, Including Abbreviations. Kew: Royal Botanic Gardens.

[35] Banda, T. M., Schwartz, W., and Caro, T. 2006. "Woody Vegetation Structure and Composition along a Protection Gradient in a Miombo Ecosystem of Western Tanzania." Forest Ecol. Manage. 230: 179-85.

[36] Kent, M. 2012. Vegetation Description and Analysis: A Practical Approach, 2nd ed.. New York: Wiley-Blackwell.

[37] Angers, V. A., Messier, C., Beaudet, M., and Leduc, A. 2005. "Comparing Composition and Structure in Old-Growth and Harvested (Selection and Diameter-Limit Cuts) Northern Hardwood Stands in Quebec.” Forest Ecol. Manage. 217 (2-3): 275-93.

[38] Bonoua, W., Glèlè Kaka, R., Assogbadjo, A. E., Fonton, H. N., and Sinsin, B. 2009. "Characterization of Afzelia africana Sm. Habitat in the Lama Forest Reserve of Benin." Forest Ecol. Manage. 258 (7): 1084-92.

[39] Zar, J. H. 1984. Biostatistical Analysis. London: Prentice-Hall International Editions.

[40] McCune, B., and Mefford, M. J. 2011. PC-ORD Version 6: Multivariate Analysis of Ecological Data. Ore: Gleneden Beach.

[41] Sokal, R. R., and Rohlf, F. J. 1995. Biometry: The Principles and Practice of Statistics in Biological Research. New York: Freeman Publisher.

[42] Mbwambo, L., Valkonen, S., and Kuutti, V. 2007. "Structure and Dynamics of Miombo Woodland Stands at Kitulangalo Forest Reserve, Tanzania." In Proceedings of the 1st MITMIOMBO Project-Management of Indigenous Tree Species for Ecosystem Restoration and Wood Production in Semi-Arid Miombo Woodlands in Eastern Africa, 10-9.
[43] Huang, W., Pohjonen, V., Johansson, S., Nashanda, M., Katigula, M. I., and Luukkanen, O. 2003. "Species Diversity, Forest Structure and Species Composition in Tanzanian Tropical Forests." Forest Ecol. Manage. 173: 11-24.

[44] Isango, J. 2007. "Stand Structure and Tree Species Composition of Tanzania Miombo Woodlands: A Case Study from Miombo Woodlands of Community Based Forest Management in Iringa District." In Proceedings of the 1st MITMIOMBO Project-Management of Indigenous Tree Species for Ecosystem Restoration and Wood Production in Semi-Arid Miombo Woodlands in Eastern Africa, 43-56.

[45] Ryan, C. M., and Williams, M. 2011. "How Does Fire Intensity and Frequency Affect Miombo Woodland Tree Populations and Biomass?" Ecol. Apply. 21 (1): 48-60.

[46] Shirima, D. D., Munishi, P. K. T., Lewis, S. L., Burgess, N. D., Marshall, A. R., Balmford, A., Swetnam, R. D., and Zahabu, E. M. 2011. "Carbon Storage, Structure and Composition of Miombo Woodlands in Tanzania's Eastern Arc Mountains." Afric. J. Ecol. 49 (3): 332-42.

[47] Mohamed, B. S. 2008. "Impact of Joint Forest Management on Handeni Hill Forest Reserve and Adjacent Communities, Tanga, Tanzania.” M.Sc. thesis, Sokoine University of Agriculture, Tanzania.

[48] Magurran, A. E. 2004. Measuring Biological Diversity. Oxford: Blackwells.

[49] Cauldwell, A. E., and Zieger, U. 2000. "A Reassessment of the Fire-Tolerance of Some Miombo Woody Species in the Central Province, Zambia." Afric. J. Ecol. 38 (2): 138-46.

[50] Nord-Larsen, T., and Cao, Q. V. 2006. "A Diameter Distribution Model for Even-Aged Beech in Denmark." Forest Ecol. Manage. 231: 218-25.

[51] Mwakalukwa, E. E., Meilby, H., and Treue, T. 2014. "Floristic Composition, Structure and Species Associations of Dry Miombo Woodland in Tanzania." Biodiversity 2: 1-15. 